\title{
Manufacturing and Macroscopic Properties of Cold Sprayed Cu-Ga Coating Material for Sputtering Target
}

\author{
Young-Min Jin, Min-Gwang Jeon, Dong-Yong Park ${ }^{a}$, Hyung-Jun Kim ${ }^{b}$, \\ Ik-Hyun $\mathrm{Oh}^{c}$ and Kee-Ahn Lee* \\ School of Advanced Materials Engineering, Andong National University, Andong 760-749, Korea \\ ${ }^{a}$ Tae-Kwang Tech., Gyeongju 780-874, Korea \\ ${ }^{b}$ RIST, Pohang 790-600, Korea \\ ${ }^{c}$ KITECH, Gwangju 500-480, Korea
}

(Received June 1, 2013; Accepted August 12, 2013)

\begin{abstract}
This study attempted to manufacture a $\mathrm{Cu}-\mathrm{Ga}$ coating layer via the cold spray process and to investigate the applicability of the layer as a sputtering target material. In addition, changes made to the microstructure and properties of the layer due to annealing heat treatment were evaluated, compared, and analyzed. The results showed that coating layers with a thickness of $520 \mathrm{~mm}$ could be manufactured via the cold spray process under optimal conditions. With the $\mathrm{Cu}-\mathrm{Ga}$ coating layer, the $\alpha-\mathrm{Cu}$ and $\mathrm{Cu}_{3} \mathrm{Ga}$ were found to exist inside the layer regardless of annealing heat treatment. The microstructure that was minute and inhomogeneous prior to thermal treatment changed to homogeneous and dense with a more clear division of phases. A sputtering test was actually conducted using the sputtering target $\mathrm{Cu}-$ Ga coating layer ( $\sim 2 \mathrm{~mm}$ thickness) that was additionally manufactured via the cold-spray coating process. Consequently, this test result confirmed that the cold sprayed $\mathrm{Cu}-\mathrm{Ga}$ coating layer may be applied as a sputtering target material.
\end{abstract}

Key words: Cu-Ga, Cold Spray deposition, Sputtering target, Annealing heat treatment, Coating

\section{Introduction}

Nonferrous metals including $\mathrm{Cu}-\mathrm{Ga}$ alloys (CG $(\mathrm{Cu}-\mathrm{Ga})$, CIG (Cu-In-Ga), and CIGS (Cu-In-Ga-Se)) have high energy absorption coefficient $\left(10^{4} \mathrm{~cm}^{-1}\right.$ or above) with their stable optical voltage characteristics, they are used widely as material for thin-film solar cells (TFSC). Recent advances in the IT/ET industry have drastically increased demand for sputtering target material [1-4], which has sparked a growing interest in research and development of energysmart, nonferrous sputtering target material.

The properties of sputtering target material have significant effects on those of the thin films to be manufactured. Thus, to produce consistent, superior-quality films, the target material must have high-performance, high-efficiency properties with purity ranging from $2 \mathrm{~N}(99 \%)$ to $4 \mathrm{~N}(99.99 \%)$, a grain size that does not exceed $50 \mu \mathrm{m}$, and a density of $99.9 \%$ or above guaranteed via purity, density, and grain size control
[5-9]. In general, the most commonly used conventional processes of manufacturing the target material include extrusion molding, cold rolling, powder sintering, and hot isostatic pressing (HIP). Note, however, that these processes pose limitations in terms of the control of size and homogeneity in grain microstructure, and the formation of high-density sputtering target material. In addition, they are very expensive when improving performance is attempted to achieve highpurity, high-density manufacture [6].

The cold spray process manufacture high-density coating layers by accelerating the speed of metal or mixed-material powders with average particle size of $1-50 \mathrm{~mm}$ up to supersonic speeds of $500-1200 \mathrm{~m} / \mathrm{s}$ using high-pressure compressed gas [10]. With this manufacturing method, metal or mixed-material powders are subjected to intensive plastic deformation upon impact in solid state at a temperature well below the melting point. The cold spray process offers advantages over the conventional thermal

*Corresponding Author : Kee-Ahn Lee, TEL: +82-54-820-512, FAX: +82-54-820-6126, E-mail: keeahn@andong.ac.kr 
spray processes since it helps overcome oxidation-induced phase alteration, property deterioration, and other weaknesses found in those methods $[11,12]$. The cold spray process is judged to be a valuable coating technique that is capable of manufacturing high-density, high-purity sputtering target material. However, most studies on the cold spray coating process have been limited to, the manufacture of coating layers and property evaluations in terms of materials such as $\mathrm{Cu}$ and $\mathrm{Ti}$, the some properties of density and conductivity, heat treatment effects, and applicability as components in the electronics/automobile/electrical industries [14,15]. Recently, authors have firstly reported the manufacturing of $\mathrm{Cu}-\mathrm{In}$ material by using cold spray process [13].

As for Cu-Ga-based nonferrous metals, the scope of research is limited to the properties of $\mathrm{Cu}-\mathrm{Ga}$-based thin films manufactured via PVD and CVD $[4,7,16]$. No studies have been carried out to investigate $\mathrm{Cu}-\mathrm{Ga}$ based coating manufacture and properties for application as target material using cold spraying. Research on property-improving methods has been conducted in some areas such as changes in the properties of thin films using conventional powder metallurgy according to sintering temperature [17] and powder milling duration [18] during target manufacture. However, very few researches have been done on changes in the properties of target material following annealing heat treatment.

This study sought to manufacture a $\mathrm{Cu}-\mathrm{Ga}$ coating layer using cold spray process. It also investigated changes in the microstructures and properties of the coating layer as a result of annealing heat treatment, which was designed to improve its properties. The possibility of applying the cold sprayed $\mathrm{Cu}-\mathrm{Ga}$ coating layer as a sputtering target material was also examined.

\section{Experimental Procedure}

This study used $\mathrm{Cu}-\mathrm{Ga}$ powder manufactured by company $\mathrm{C}$ (Korea) to perform the cold spray coating. The applied $\mathrm{Cu}-\mathrm{Ga}$ powders consist of round particles ranging from 2$85 \mu \mathrm{m}$ in size (average powder particle size $=28.3 \mu \mathrm{m}$ ), and composed of $\mathrm{Cu}-20 \mathrm{at} \% \mathrm{Ga}$. Fig. 1 presents the shape of Cu-Ga powder (Fig. 1(a)), observed via SEM and the powder particle size distribution (Fig. 1(c)). The Fig. 1(b) also presents the SEM result, which was taken after etching of the sectional powder. It was observed that the $\mathrm{Cu}-\mathrm{Ga}$ powder consisted of asymmetrical grains, with an inhomogeneous grain boundary.

To produce coating layers using $\mathrm{Cu}-\mathrm{Ga}$ powder, preliminary tests were conducted. Using the optimal process conditions
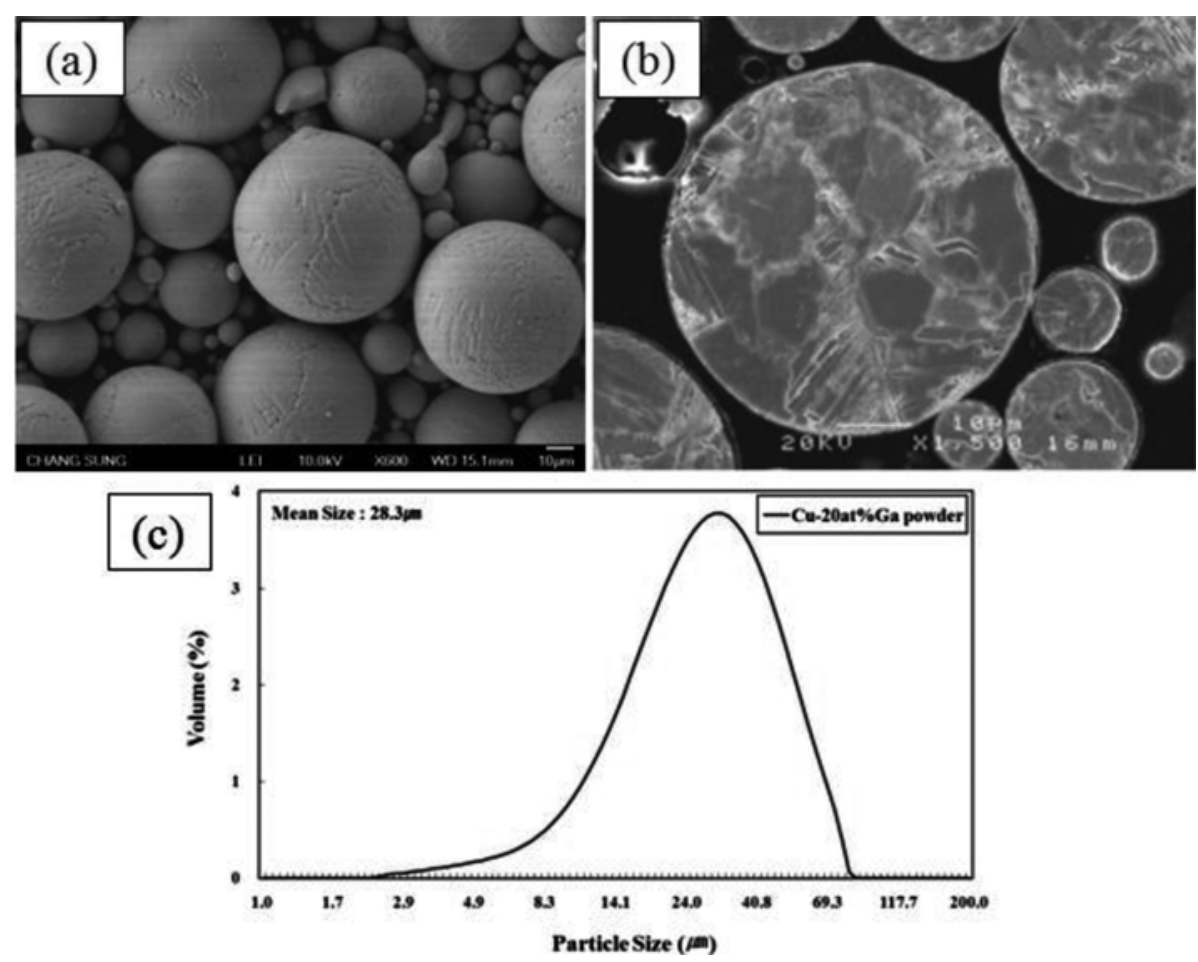

Fig. 1. Characteristics of powders used in this study - (a) the shape of Cu-Ga powders (b) cross-sectional SEM observation result of $\mathrm{Cu}-\mathrm{Ga}$ powder and (c) the size distribution of powder particle of $\mathrm{Cu}-\mathrm{Ga}$ powder. 
Table 1. Optimal coating manufacture process conditions of cold spraying selected from preliminary tests

\begin{tabular}{lc}
\hline \hline & $\begin{array}{c}\text { CG coating } \\
(\mathrm{Cu}-20 \text { at. } \% \mathrm{Ga})\end{array}$ \\
\hline Gas temp. $\left({ }^{\circ} \mathrm{C}\right)$ & 700 \\
Powder preheat temp. $\left({ }^{\circ} \mathrm{C}\right)$ & 520 \\
Substrate preheat temp. $\left({ }^{\circ} \mathrm{C}\right)$ & $\mathrm{No}$ \\
Pressure (bar) & 30 \\
Gas & $\mathrm{N}_{2}$ \\
Gun travelling speed $(\mathrm{mm} / \mathrm{sec})$ & 50 \\
Spray distance $(\mathrm{mm})$ & 30 \\
Substrate & Pure Cu \\
Blasting & Yes \\
\hline
\end{tabular}

suggested by the preliminary tests for this study, the coating process was executed. Table 1 provides a summary of the cold spray process conditions for the $\mathrm{Cu}-\mathrm{Ga}$ coating layers used in the study. In executing cold spraying, nitrogen $\left(\mathrm{N}_{2}\right)$ temperature for injection was maintained at $700^{\circ} \mathrm{C}$ including a spray distance of $30 \mathrm{~mm}$. To help raise coating efficiency, this study also conducted pre-heating for the $\mathrm{Cu}-\mathrm{Ga}$ powder at $520^{\circ} \mathrm{C}$. In manufacturing coating layers, pure $\mathrm{Cu}$ was used for the substrate. To evaluate the resultant purity from the cold spray process, analysis was done on the ICP (Inductive Coupled Plasma) composition of the initial $\mathrm{Cu}-\mathrm{Ga}$ powder and the manufactured coating layer. For the analysis of ICP contents of powder, $10 \mathrm{~g}$ of the powders was used; in the case of coating layers, chips were made from many areas representing individual parts to make $10 \mathrm{~g}$ samples into ICP.

Afterward, the cold sprayed coating materials were subjected to annealing heat treatments lasting one hour under an atmosphere of Ar with a purity of $99.999 \%$ and at temperatures of $200^{\circ} \mathrm{C}, 400^{\circ} \mathrm{C}, 600^{\circ} \mathrm{C}$, and $800^{\circ} \mathrm{C}$. To observe the changes in the microstructure of the cold sprayed coating layer and the annealing-treated layer, samples were etched in $10 \mathrm{ml} \mathrm{H}_{2} \mathrm{O}_{2}+50 \mathrm{ml} \mathrm{NH} \mathrm{NH}_{4} \mathrm{OH}$ solution and subsequently subjected to Scanning Electron Microscopy (SEM: Tescan, VEGA I ILMU) examination. In addition, Energy Dispersive Spectrometry (EDS), X-Ray Diffraction (XRD: Rigaku, D/MAXRAPIDS), and Electron Probe Micro-Analyzer (EPMA) were used to analyze the created phases. To identify the changes in characteristics resulting from annealing, properties such as porosity and hardness were measured. For porosity, 15 measurements were performed via image analyzer to obtain the average value. For the hardness, measurements were performed fifteen times at a load of $10 \mathrm{~g}$ each using Vickers hardness tester (Akashi, AVK-C100). The median value excluding the maximum and minimum values was used. To examine the possibility that the $\mathrm{Cu}-\mathrm{Ga}$ coating layer manufactured via the cold spray process may be applied as a sputtering target material, the coating material (approx. $2 \mathrm{~mm}$ thick) was additionally manufactured by cold spraying, machined to the diameter of 2 inch, then an actual sputtering test was attempted to form a thin film.

\section{Results and Discussion}

Fig. 2 presents the $\mathrm{Cu}-\mathrm{Ga}$ coating layer that was manufactured through the cold spray process under the process conditions stated in Table 1. The manufactured $\mathrm{Cu}-\mathrm{Ga}$ coating layer has a thickness of approximately $520 \mu \mathrm{m}$. The ICP analysis results of the initial powder and the manufactured coating layer are presented in Table 2. The purity of $\mathrm{Cu}-\mathrm{Ga}$ coating layer was observed at $99.68 \%$, which is a drop from the initial powder's $99.98 \%$. Here, with the $\mathrm{Cu}-\mathrm{Ga}$ material, the decrease of its purity after coating was approximately $0.3 \%$, which is somewhat high,

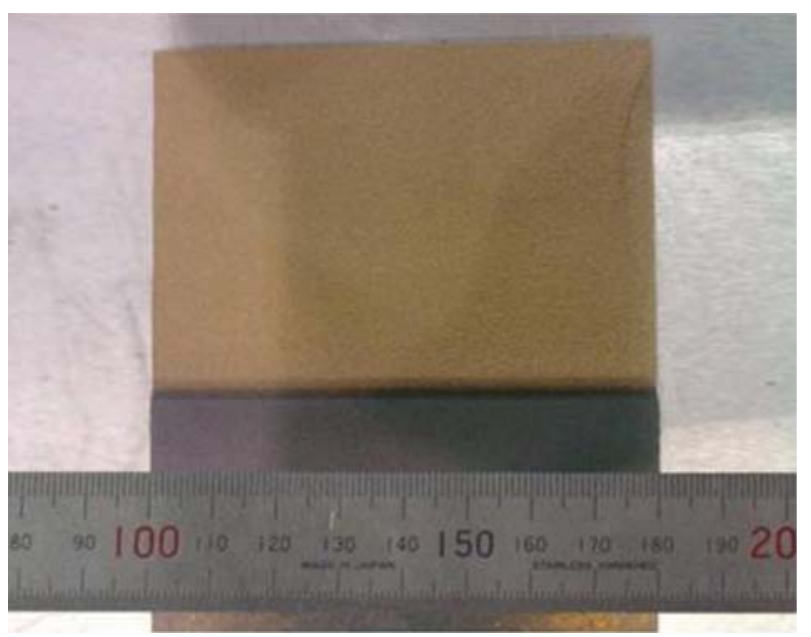

Fig. 2. Macro images of the cold sprayed samples of the $\mathrm{Cu}$ Ga coating layer.

Table 2. Results of purity comparison using ICP analysis for $\mathrm{Cu}$-Ga powder and coating layer [Unit : wt.\%]

\begin{tabular}{lccc}
\hline \multicolumn{1}{c}{ Composition } & $\mathrm{Cu}$ & $\mathrm{Ga}$ & Impurity \\
\hline $\begin{array}{l}\text { CG powder } \\
(\mathrm{Cu}-20 \text { at.\%Ga=Cu-21.47 wt.\%Ga) }\end{array}$ & Bal. & 21.19 & 0.08 \\
$\begin{array}{l}\text { CG coating layer } \\
(\mathrm{Cu}-20 \text { at.\%Ga=Cu-21.47 wt.\%Ga) }\end{array}$ & Bal. & 21.04 & 0.32 \\
\hline
\end{tabular}



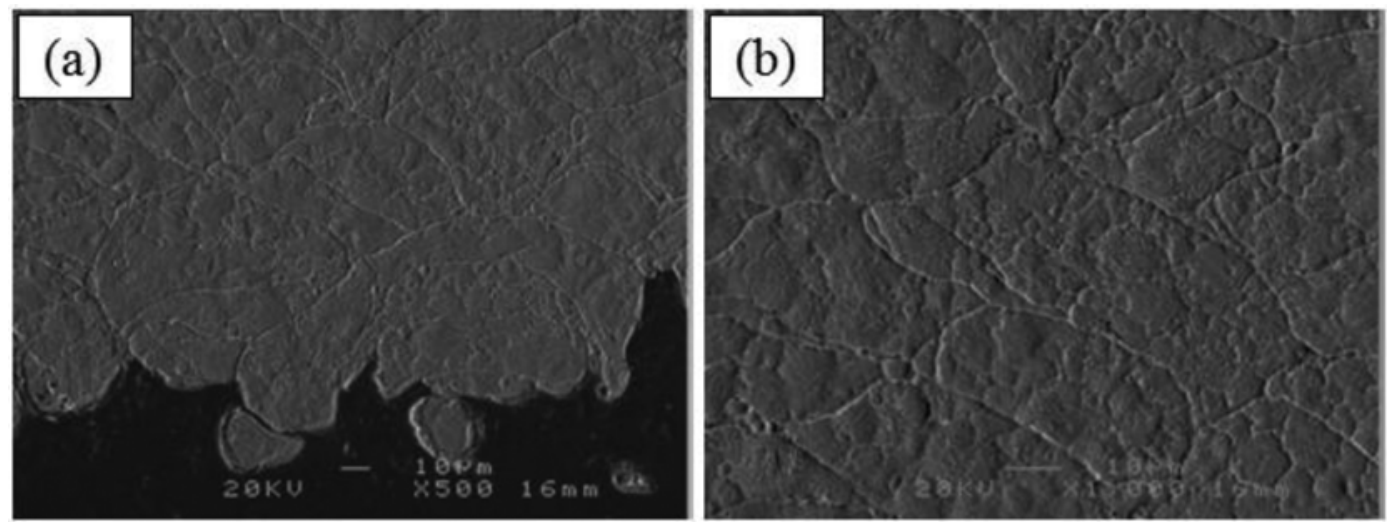

Fig. 3. SEM microstructure of the manufactured coating layer (a) surrounding areas of the Cu-Ga coating layer's interfaces; (b) highmagnification images of the inside of the $\mathrm{Cu}-\mathrm{Ga}$ coating layer.

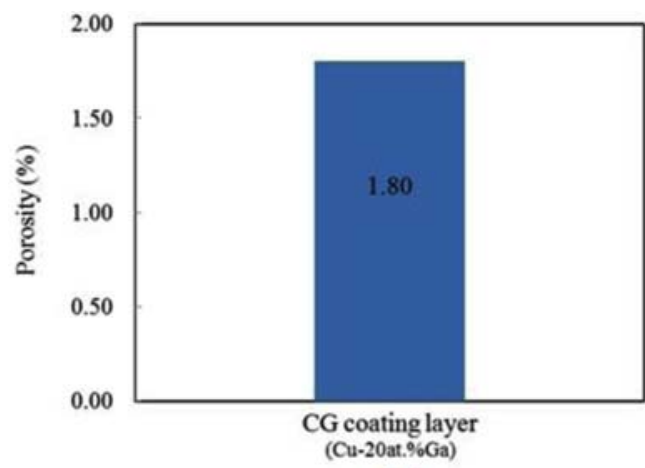

(a)

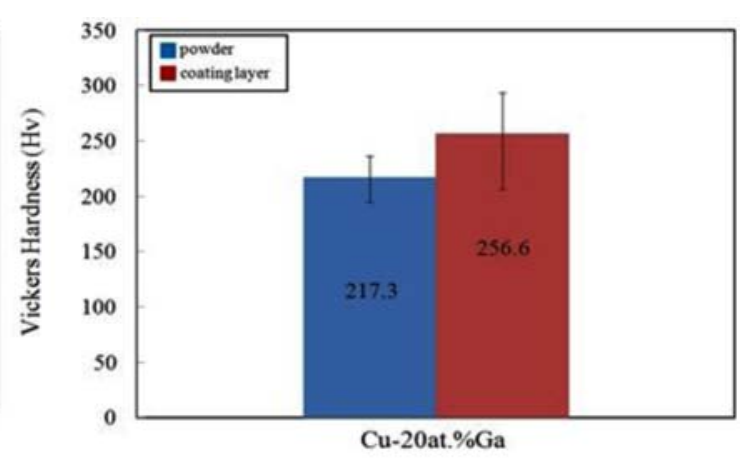

(b)

Fig. 4. Results of the porosity (a) and hardness (b) measurements of $\mathrm{Cu}$-Ga powders and coating layer.

compared to the purity change $(0.03 \%)$ of pure $\mathrm{Cu}$ and $\mathrm{Cu}-\mathrm{In}$ in the previous study [13]. It is noteworthy that the ICP analysis results of powder and coating layer revealed higher oxygen content $(0.2 \%$ increase $)$ after coating versus other elements $\left(\mathrm{Fe}, \mathrm{Ni}, \mathrm{Sn}, \mathrm{N}_{2}\right)$. This appears to result from the preheating of the powder, which was additionally performed in the manufacture of the $\mathrm{Cu}-\mathrm{Ga}$ coating layer.

Fig. 3 presents the post-etching microstructure of the coating layer made of $\mathrm{Cu}-\mathrm{Ga}$ powder. As seen in the figure, the particles initially deposited along the interface of the $\mathrm{Cu}$ Ga coating layer appear round. However, when the microstructure (Fig. 3(b)) inside the coating layer is examined closely, the powder particles roughly appear elongated perpendicularly to the spraying direction, and the dense microstructure by plastic deformation is observed. Fig. 4 presents the porosity (Fig. 4(a)) and hardness (Fig. 4(b)) of the $\mathrm{Cu}-\mathrm{Ga}$ coating layer. The porosity of the $\mathrm{Cu}-\mathrm{Ga}$ coating layer is $1.8 \%$, which is relatively low compared to that of $\mathrm{Cu}$-In (3.54\%) which was produced in the previous study [13]. Cu-Ga materials subjected to hardness testing revealed
217.3Hv for $\mathrm{Cu}-\mathrm{Ga}$ powder and 256.6 Hv for Cu-Ga coating layer. These values $(\mathrm{Cu}-\mathrm{Ga})$ were lower than $\mathrm{Cu}-\mathrm{In}$ (powder 448.5 Hv; coating layer - 476.6 Hv) [13]. Furthermore, the hardness of the $\mathrm{Cu}-\mathrm{Ga}$ coating layer showed a slight increase, compared to that of the initial powder (217.3 $\mathrm{Hv}$ ). It is understood that this resulted from, according to the studies done by S. H. Kwon et al. [14] and T. Stoltenhoff et al. [19], work hardening that was caused by plastic deformation in the manufacture of the coating layer via the cold spray coating process.

The $\mathrm{Cu}-\mathrm{Ga}$ binary phase diagram confirms that $\mathrm{Cu}-$ 20 at. $\% \mathrm{Ga}$ consists of the two equilibrium phases of $\alpha-\mathrm{Cu}$ and $\mathrm{Cu}_{3} \mathrm{Ga}(\zeta)$ [20]. To identify phase changes before and after the cold spray process, X-ray diffraction (XRD) of the initial powder and the manufacture coating layer was analyzed. Fig. 5 presents the results of this analysis: the $\mathrm{Cu}-\mathrm{Ga}$ coating layer is observed with the same peak as in the initial powder, showing no newly generated phase after the cold spray process. This result signifies that the cold spray process is suitable to maintaining the property of the 


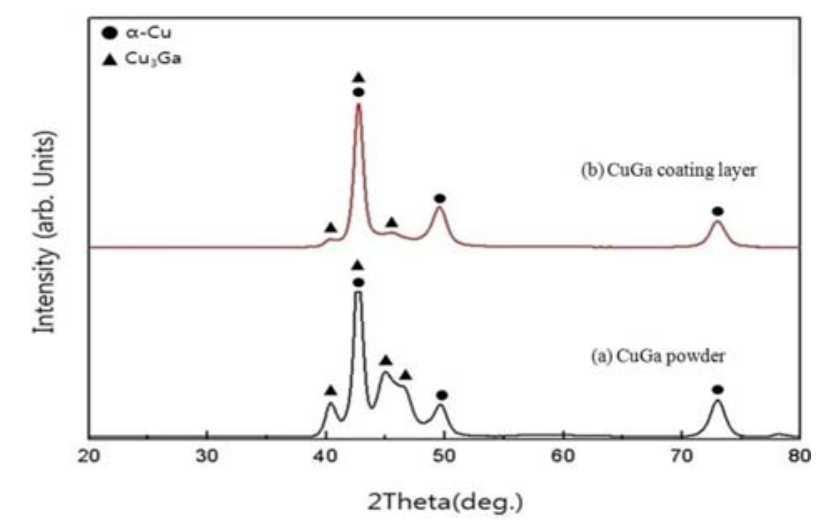

Fig. 5. Results of XRD analysis of the Cu-Ga powder and the Cu-Ga coating layer.

initial powder and enabling the manufacture of a superior coating layer without generating a new phase. We found that the $\mathrm{Cu}-\mathrm{Ga}$ powder and the $\mathrm{Cu}-\mathrm{Ga}$ coating layer $\mathrm{C} \mathrm{Cu}-$ 20at.\%Ga composition) are composed of two representative $\alpha$ $\mathrm{Cu}$ and $\mathrm{Cu}_{3} \mathrm{Ga}(\zeta)$ phases [20]. Subsequently, to identify the distribution of $\alpha-\mathrm{Cu}$ and $\mathrm{Cu}_{3} \mathrm{Ga}(\zeta)$ that are present inside the $\mathrm{Cu}-\mathrm{Ga}$ coating layer, via EPMA, mapping analysis for each element was performed, with the results presented in Fig. 6. Over the entire $\mathrm{Cu}-\mathrm{Ga}$ coating layer, the two elements $\mathrm{Cu}$ and $\mathrm{Ga}$ are evenly distributed except for some of the indicated areas, which show a tiny difference. The
$\mathrm{Cu}_{3} \mathrm{Ga}(\zeta)$ phase is observed with a relatively lower distribution of $\mathrm{Cu}$ and higher distribution of $\mathrm{Ga}$ element compared to the matrix $(\alpha-\mathrm{Cu})$. Overall, the phases are very minute and irregular, making identification difficult.

Fig. 7 shows the result of changes in porosity (a) and hardness (b) following annealing thermal treatment that was performed to improve the properties of coating layer as a sputtering target material. According to the porosity changes by annealing temperature in Fig. 7(a), it was checked that as the temperature increased, the porosity decreased. Under thermal conditions of $800^{\circ} \mathrm{C} / 1 \mathrm{hr}$, the value reached its lowest level, $0.74 \%$. This signifies that while the microstructure becomes denser in the process of recovery, crystallization and grain growth, the porosity decreases $[14,21]$. Here, it is noteworthy that despite the one-hour thermal treatment time, the porosity decreased to approximately $1 \%$, compared to the initial value $(1.8 \%)$. This result indicates that the density based on the porosity was improved to approximately $99.26 \%$ due to thermal treatment from the initial level, $98.2 \%$, signifying that annealing thermal treatment is significant for improving density. It confirms that as the annealing temperature increases, as seen in Fig. 7(b), the hardness of the coating layer continuously decreases, reaching the lowest value,

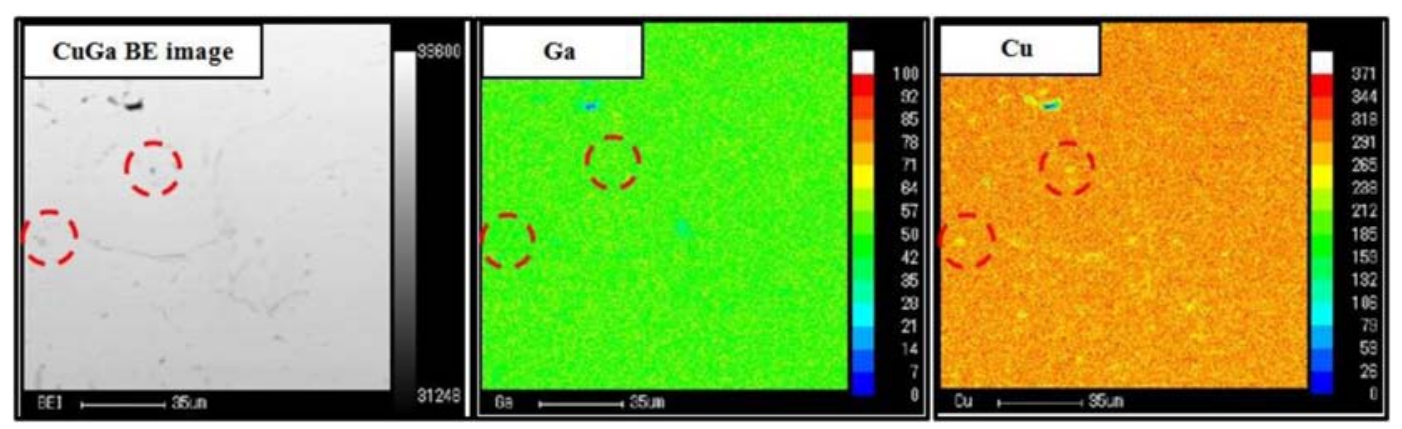

Fig. 6. Results of EPMA mapping analysis of the Cu-Ga coating layer's non-heat treatment.

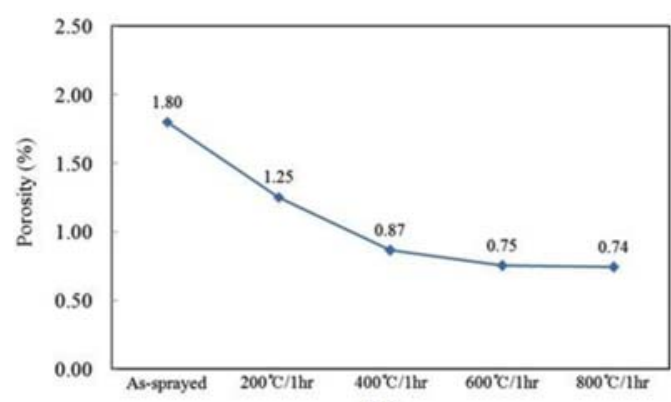

(a)

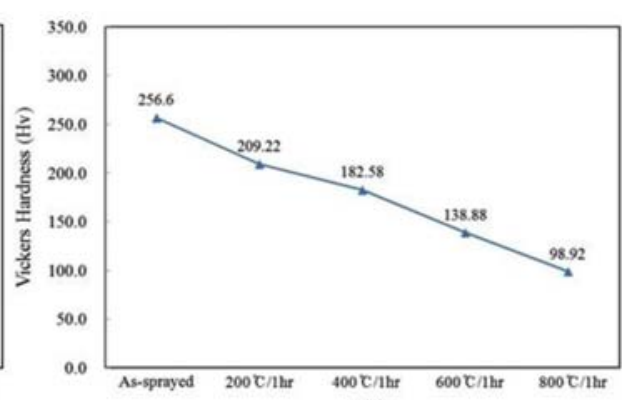

(b)

Fig. 7. Changes in the porosity (a) and hardness (b) of the Cu-Ga coating layer following annealing treatment. 

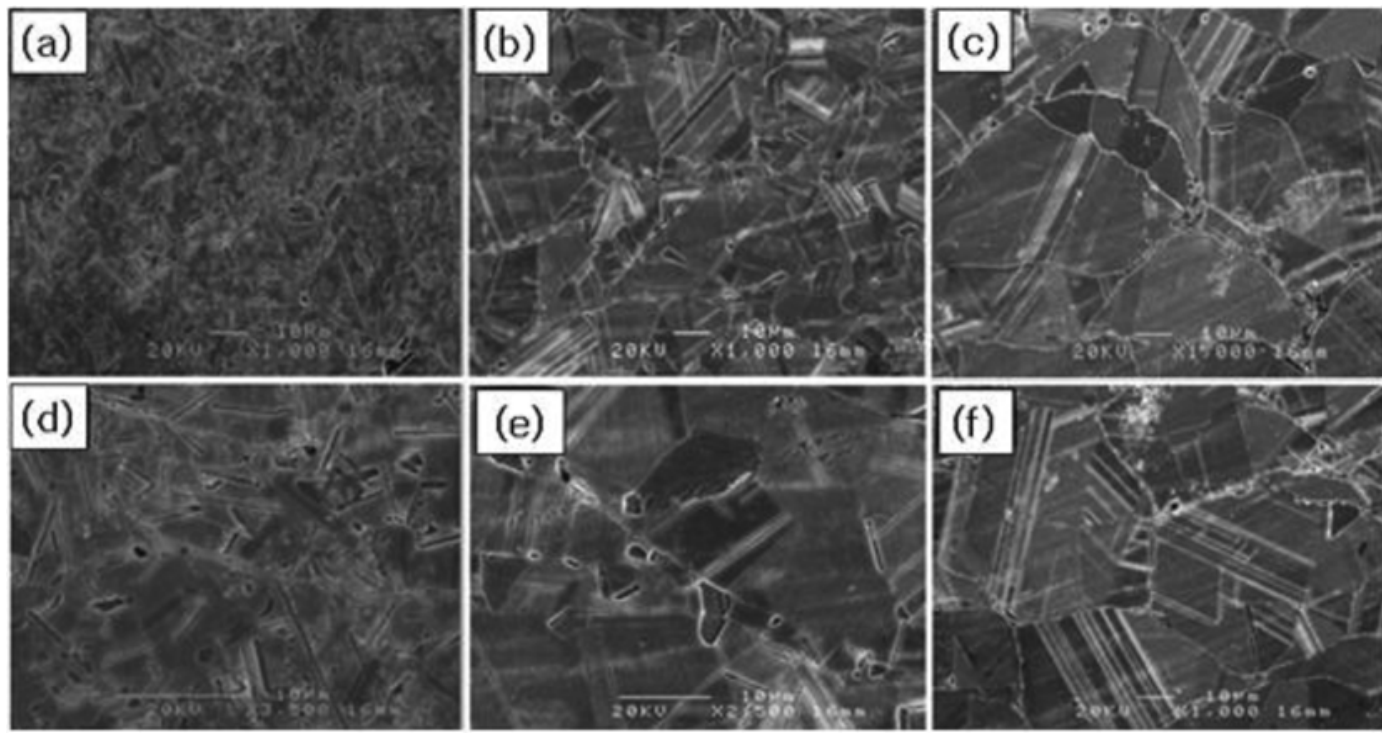

Fig. 8. Changes in the microstructure of the $\mathrm{Cu}-\mathrm{Ga}$ coating layer following the annealing treatment: (a) $400^{\circ} \mathrm{C} / 1 \mathrm{hr}$ annealed; (b) $600^{\circ} \mathrm{C} / 1 \mathrm{hr}$ annealed; (c) $800^{\circ} \mathrm{C} / 1 \mathrm{hr}$ annealed; (d) $400^{\circ} \mathrm{C} / 1 \mathrm{hr}$ annealed under high magnification; (e) $600^{\circ} \mathrm{C} / 1 \mathrm{hr}$ annealed under high magnification; (f) $800^{\circ} \mathrm{C} / 1 \mathrm{hr}$ annealed under high magnification.

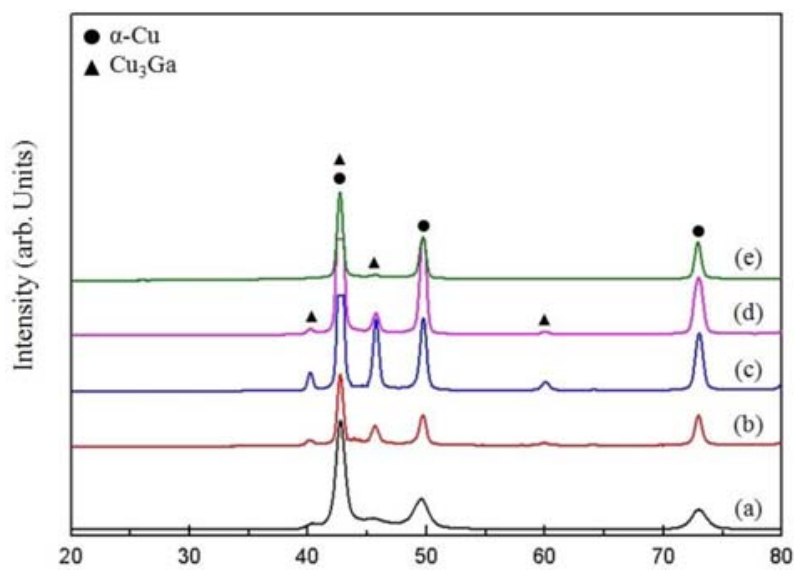

Fig. 9. Results of the XRD analyses following the $\mathrm{Cu}-\mathrm{Ga}$ coating layer's annealing treatment: (a) as-sprayed; (b) $200^{\circ} \mathrm{C} / 1 \mathrm{hr}$ heat-treated; (c) $400^{\circ} \mathrm{C} / 1 \mathrm{hr}$ heat-treated; (d) $600^{\circ} \mathrm{C} / 1 \mathrm{hr}$ heattreated; (e) $800^{\circ} \mathrm{C} / 1 \mathrm{hr}$ heat-treated.
98.2 $\mathrm{Hv}$, under the $800^{\circ} \mathrm{C} / 1 \mathrm{hr}$ condition.

Fig. 8 shows the results of observation of the ((a) $400^{\circ} \mathrm{C} / 1$ hr, (b) $600^{\circ} \mathrm{C} / 1 \mathrm{hr}$, (c) $800^{\circ} \mathrm{C} / 1 \mathrm{hr}$ ) SEM microstructure in accordance with annealing thermal treatment of cold spray coating material using $\mathrm{Cu}-\mathrm{Ga}$ powder. In the process of thermal treatment, recrystallization (a) starts developing in the particle interface, and at over $600^{\circ} \mathrm{C}$. Moreover, after the final thermal process at $800^{\circ} \mathrm{C} / 1 \mathrm{hr}$, the originally irregular structure begins showing relatively regular grains.

Fig. 9 displays the XRD analysis used for identification of the phase changes by thermal treatment. With $\mathrm{Cu}-\mathrm{Ga}$, it is confirmed that regardless of annealing temperature, the entire coating layer consists of $\alpha-\mathrm{Cu}$ and $\mathrm{Cu}_{3} \mathrm{Ga}$, showing no new phase.

Subsequently, Fig. 10 presents the analysis results of the mapping of EPMA composition that was performed after

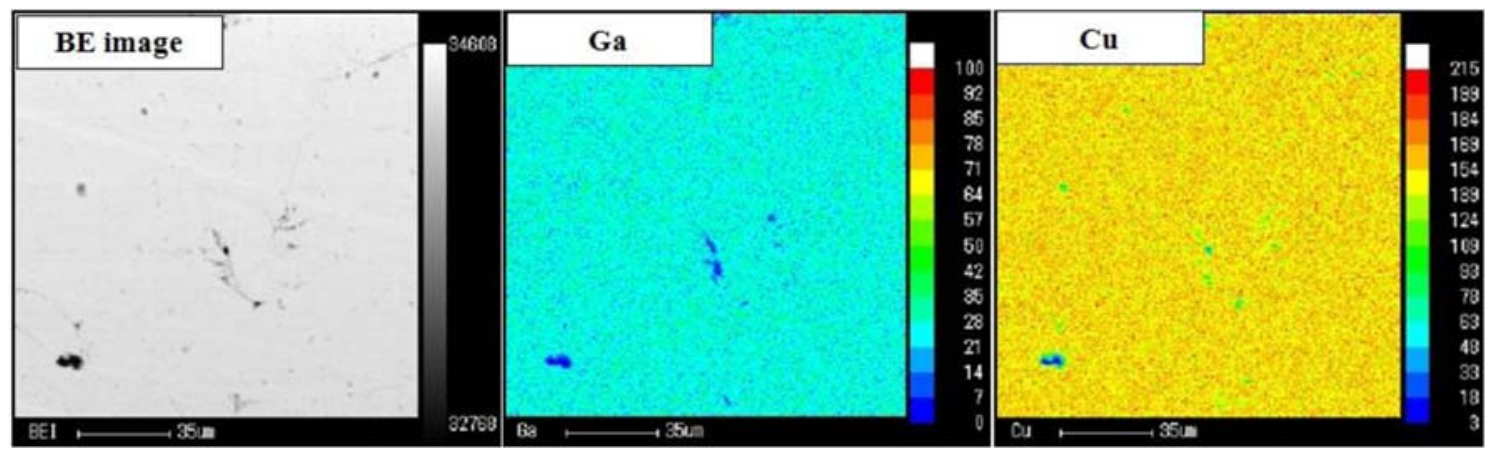

Fig. 10. Results of EPMA mapping analyses following the $\mathrm{Cu}-\mathrm{Ga}$ coating layer's $400^{\circ} \mathrm{C} / 1 \mathrm{hr}$ annealing treatment. 

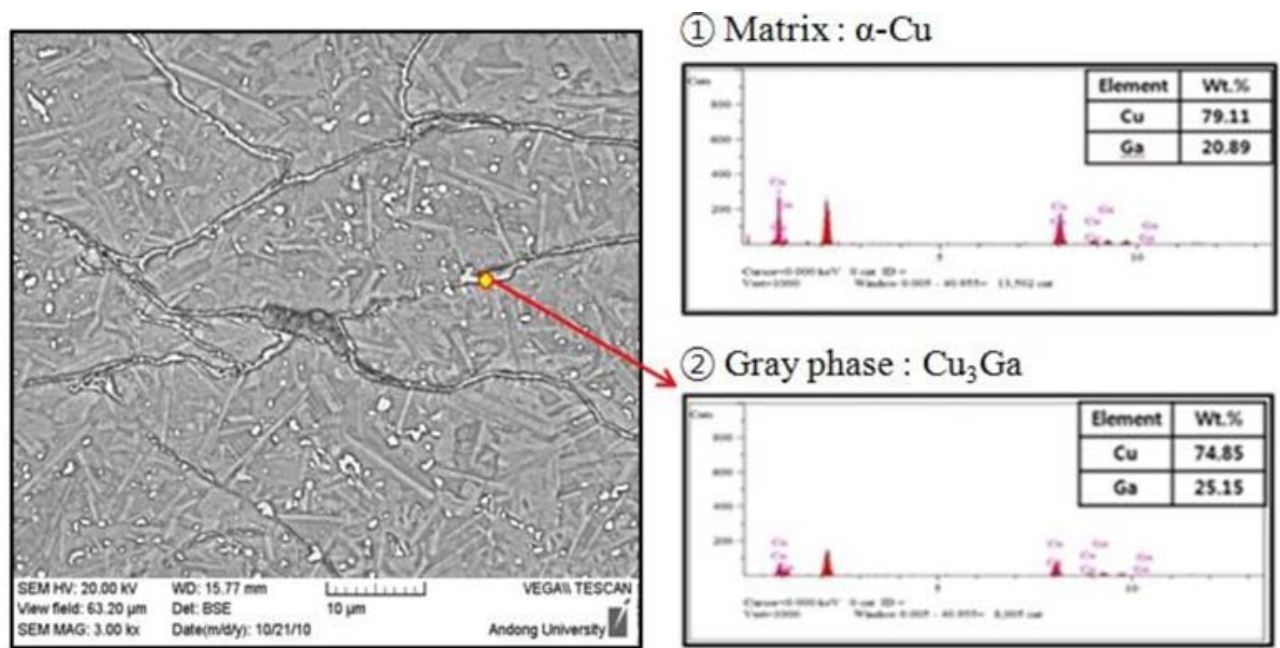

Fig. 11. Results of SEM and EDS analyses following the Cu-Ga coating layer's $400^{\circ} \mathrm{C} / 1 \mathrm{hr}$ annealing treatment.

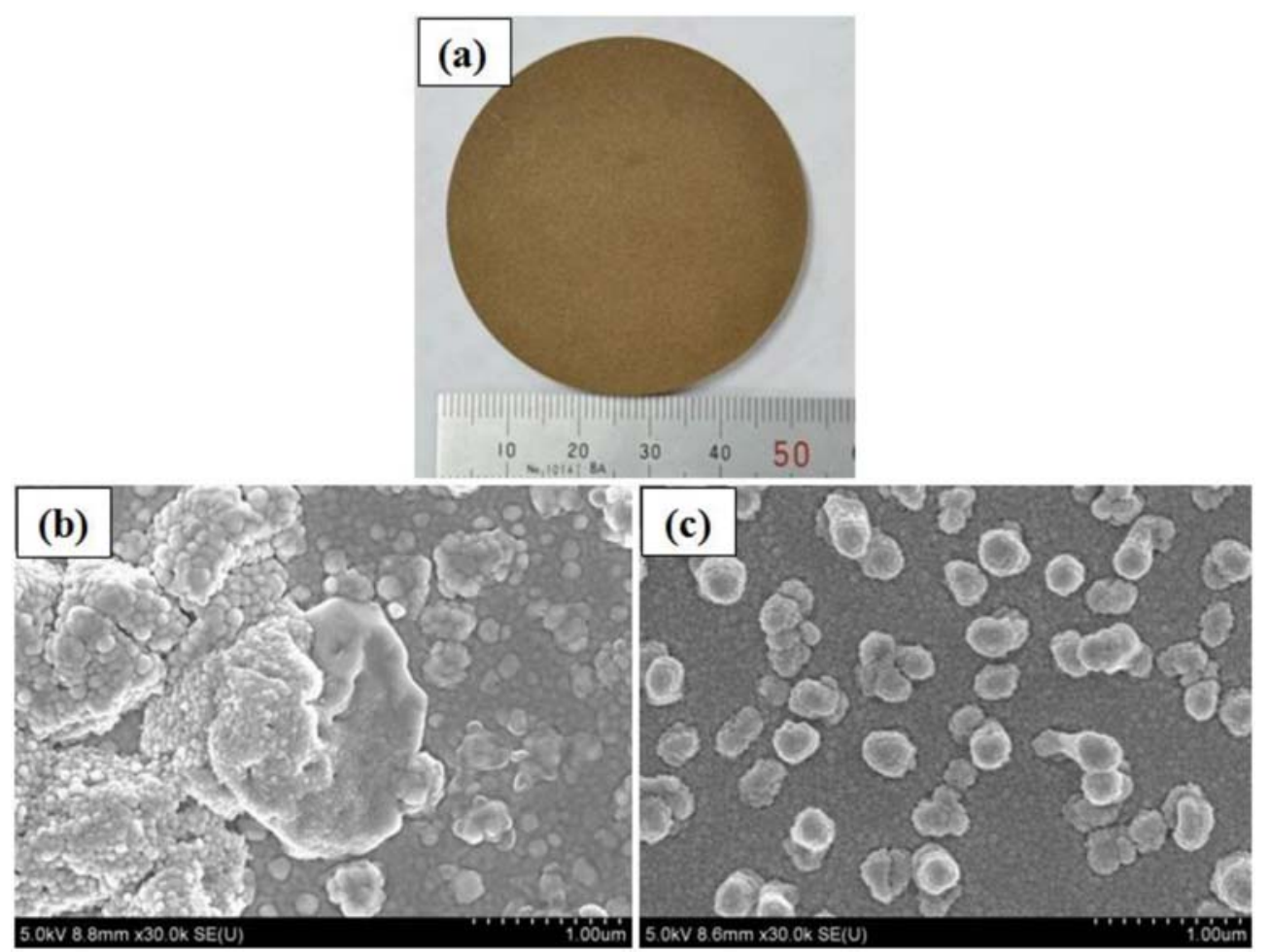

Fig. 12. Results of sputtering test with the $\mathrm{Cu}$-Ga coating material: (a) $\mathrm{Cu}$-Ga coating material manufactured by cold spray process for sputtering test; (b) Surficial SEM micrograph of thin film formed by sputtering test using commercially available sputtering target; (c) that using cold sprayed sputtering target material in (a).

annealing at $400^{\circ} \mathrm{C} / 1 \mathrm{hr}$ as a typical example; and Fig. 11 presents the EDS analysis results. In the observation of the microstructure prior to thermal treatment (Fig. 6), $\mathrm{Cu}$ and Ga elements are evenly distributed overall, with structural inhomogeneity, and they are too fine to differentiate the phases on the microstructure. After the $400^{\circ} \mathrm{C}$ thermal treatment, the distribution of every component is easily identified (Fig. 10). Based on the EDS analysis in Fig. 11 and the mapping analysis on each element of the coating layer in Fig. 10, each phase presented in Fig. 11 is analyzed as a gray phase $\left(\mathrm{Cu}_{3} \mathrm{Ga}\right.$ phase) and matrix $(\alpha-\mathrm{Cu})$.

An actual sputtering test to create thin film was done with a $\mathrm{Cu}-20 \% \mathrm{Ga}$ target material (Fig. 12(a)) manufactured by using cold spraying, and the same test was comparatively conducted with a commercially available target material. Fig. 12((b); commercial), ((c); cold sprayed) presents the 
surface SEM observation results of those thin films that were formed via the sputtering tests. The result is that using the sputtering target $\mathrm{Cu}-\mathrm{Ga}$ coating sample manufactured via the cold spray process, an actual thin film is able to be formed. The formed thin film showed greater regularity than the thin film made from commercially available target materials. Based on the results of the sputtering tests, it is concluded that the $\mathrm{Cu}-\mathrm{Ga}$ coating layer manufactured via the cold spray process has sufficient applicability - as a sputtering target material.

\section{Conclusions}

This study attempted to manufacture the $\mathrm{Cu}-\mathrm{Ga}$ coating layer using the cold spray coating process, and analysis was done on the microstructure and property changes following heat treatment, and then an actual sputtering test was performed to investigate the applicability as target material. The following conclusions were reached:

1. After cold spray coating using $\mathrm{Cu}-\mathrm{Ga}$ powder, the powder preheating and substrate blasting was carried out, resulting in the manufacture of a coating layer $\sim 520 \mu \mathrm{m}$ thickness.

2. Analysis of the microstructure and phases of the $\mathrm{Cu}$ Ga coating layer via XRD and EPMA confirmed that the $\mathrm{Cu}-\mathrm{Ga}$ coating layer, regardless of heat treatment, is composed of the two phases: $\alpha-\mathrm{Cu}$ and $\mathrm{Cu}_{3} \mathrm{Ga}(\zeta)$.

3. The $\mathrm{Cu}-\mathrm{Ga}$ coating layer prior to the annealing process had an indefinite identification of phases and microstructural inhomogeneity. After heat treatment, in the process of recovery, recrystallization and grain growth of the structure, each phase had a relatively clear distribution with a more regular microstructure. The porosity and hardness of the initial coating layers were $1.8 \%$ and $256.6 \mathrm{Hv}$, respectively. After thermal treatment at $800^{\circ} \mathrm{C} / 1 \mathrm{hr}$, those values reached the lowest levels (porosity - $0.74 \%$; hardness - $98.92 \mathrm{Hv}$ ), and enhanced density was observed.

4. The thin film could be actually formed via a sputtering test with the $\mathrm{Cu}-\mathrm{Ga}$ coating layer manufactured through the cold spray process. Compared to the thin film manufactured using the commercially available target, the $\mathrm{Cu}-\mathrm{Ga}$ thin film showed greater regularity. These results confirmed that the $\mathrm{Cu}-\mathrm{Ga}$ coating layer manufactured via the cold spray process may be sufficiently applied- as a sputtering target material.

\section{Acknowledgement}

This research was supported by "the program for the Industrial Strategic Technology Development" and "the program for the Training of Graduate Students in Regional Innovation", in Korea.

\section{References}

[1] M. Kaelin, D. Rudmann, F. Kurdesau, T. Meyer, H. Zogg and A. N. Tiwari: Thin Solid Films., 431 (2003) 58.

[2] M. Nouiri, Z. B. Ayadi, K. Khirouni, S. Alaya, K. Djessas and S. Yapi: Mater. Sci. Eng. C, 27 (2007) 1002.

[3] K. Sakurai, R. Hunger, N. Tsuchimochi, T. Baba, K. Matsubara, P. Fons, A. Yamada, T. Kojima, T. Deguchi, H. Nadanishi and S. Niki: Thin Solid Films., 431 (2003) 6.

[4] T. Nakano, T. Suzuki, N. Ohnuki and S. Baba: Thin Solid Films., 334 (1998) 192.

[5] J. W. Lim, J. W. Bae, Y. F. Zhu, S. Lee, K. Mimura and M. Isshiki: Surf. Coat. Techno., 201 (2006) 1899.

[6] J. Sarkar, P. McDonald and P. Gilman: Thin Solid Films., 517 (2009) 1970.

[7] M. Moriyama, T. Morita, S. Tsukimoto, M. Shimada and M. Murakami: Mater. Trans., 46 (2005) 1036.

[8] K. J. Kardokus, C. T. Wu, Parfeniuk, L. Chrstopher and E. B. Jane: U.S. Patent 6, 645,427. Nov. 11, 2003 "Copper Sputtering Target Assembly and Method of Making same".

[9] C. F. Lo, P. Mcdonald, D. Draper and P. Gilman: J. Eelectro. Mater., 34 (2005) 1468.

[10] H. Thomasv and V. Steenkiste: Key Eng. Mater., 197 (2001) 59.

[11] A. Papyrin: Adv. Mater. Proc., 159 (2001) 49.

[12] H. J. Kim, C. H. Lee and Y. G. Kweon: Journal of KWS., 20 (2002) 53 (Korean).

[13] Y. M. Jin, J. H. Cho, D. Y. Park, J. H. Kim and K. A. Lee: J. Therm. Spray Techn., 20 (2011) 497.

[14] S. H. Kwon, D. Y. Park, H. J. Kim and K. A. Lee: J. Kor. Inst. Met. \& Mater., 45 (2007) 216 (Korean).

[15] W. Kroemmer, P. Heinrich and P. Richter: Thermal Spray 2003, B. R. Marple and C. Moreau: Ed., ASM International, Orlando, FL, USA., (2003) 97.

[16] O. Volobujeva, M. Altosaar, J. Raudoja, E. Mellikov, M. Grossberg, L. Kaupmees and P. Barvinschi: Solar Energy Mater. \& Solar Cell., 93 (2009) 11.

[17] S. H. Chang, J. C. Choi, S. W. Choi and I. H. Oh, Kor. J. Mater. Res., 18 (2008) 181 (Korean).

[18] B. Gabbitas, P. Cao, S. Raynova and D. L. Zhang: Maters. Sci. Forum., 534 (2007) 805.

[19] T. Stoltenhoff, C. Borchers, F. Gartner and H. Kreye: Surf. Coat. Tech., 200 (2006) 4947.

[20] H. Pop and T. B. Massalski: Acta Metall., 13 (1965) 1021.

[21] S. H. Kwon, D. Y. Park, D. Y. Lee, K. J. Euh and K. A. Lee: J. Kor. Inst. Met. \& Mater., 46 (2008) 182 (Korean). 